Nummer:

Titel:

The performance of aggregates in a single surface dressing, subjected to wear by studded tyres

Författare:

Christer Backman, Peet Höbeda

Avdelning: $\quad V$

Projektnummer: $\quad 42007-5$

Projektnamn: Stenmaterial - undersökningsmetoder och vägtekniska egenskaper Uppdragsgivare: VTI

Distribution: fri / nXfers 


\title{
IE PERFORMANCE OF AGGREGATES IN A SINGLE SURFACE DRESSING, SUBJECTED TO WEAR $\checkmark$ STUDDED TYRES
}

\author{
JMPORTEMENT DE GRANULATS EN ENDUITS SUPERFICIELS SOUMIS A L'ACTION DE PNEUS \\ CRAMPONS
}

\author{
ICKMAN Christer*, HÖBEDA Peet**
}

Jstract

Sweden, studded tyres cause considerable wear on road surfacings. The properties of aggregates are known to be of impornce, but lack of experience with road conditions has prevented relevant specifications.

1e performance of nine aggregates - in a single surface dressing - has been studied by means of small test surfacings in ad E4. The flakiness of two of the aggregates was varied, too. The change of the texture depth was determined with the 1 of a laser profilometer and sand-patch measurements. The former is considered to give more reliable results. After two ars in service, the test surfaces have been rated by an expert panel and aggregate samples have been removed from the ad after heating the binder. The changes in grading and flakiness have been analyzed.

ie macrosurface depths after two years and the changes of that property, not considering the first summers change,because particle orientation and embedment going on, correlates well with the Swedish aggregate abrasion value. Also, the flakiness the wom aggregates and reduction of that property in the road, due to traffic wear, correlate. The aggregate impact value ies not correlate. However, a fair relationship exists with the aggregate crushing in the road. Obviously, most of these partiis, that have been crushed by traffic stresses, can go on functioning in the surface dressing. The condition is, however, that proper aggregate-binder adhesion exists. The aggregate flakiness is also of importance mainly as it determines the "particle yer height" of the road surfacing. A lack in the abrasion property of an aggregate can partly be compensated by improving e tlakiness.

isumè

1 Suède, les pneus à crampons usent fortement la surface des chaussées.

a a étudié l'évolution de 9 granulats utilisés en enduits superficiels sur de petites planches expérimentales. Des mesures ont é faites : profilomètre à laser et hauteur au sable. Après 2 ans de trafic on a extrait les gravillons pour mesurer l'évolution de forme et de la granularité.

essai suédois d'abrasion se corrèle bien avec les résultats de ces constatations, ce qui n'est pas le cas de la fragmentation inamique.

a forme des gravillons joue un rôle important et une faible résistance à l'abrasion peut être en partie compensée par des grallons plus cubiques.

\section{Introduction}

uring wintertime in Sweden, studded tyres cause wear on Jad surfaces with heavy traffic. On correctly laid road irfaces, the quality of the aggregate is one of the most nportant wear-determining factors. The classification of ie aggregates for road surfacing purposes has been done urough testing particle shape and strength, Swedish flakiess and impact value respectively. The first mentioned lethod represents the approximate average ratio between re width and thickness of the particles, obtained by sieing the aggregate on quadratic and slotted formed screens.

\footnotetext{
Skå nska Cementguteriet. Box 49, S-123 51 F.ARSTA.

* Swedish Road and Trafic Research Institute (VTI), Fack, 58101 Linkoping, (Sweden).
}

In cases with similar aggregate sizes, the impact value gives a good correlation with results from foreign testing methods for aggregate strength. The impact value is strongly influenced by the flakiness value. The polishing of road surfacing aggregates is not considered to be a problem in Sweden and no test exists. This is considered partly due to the petrological characteristics of the aggregates, partly to the wear of studded tyres.

The wear caused by studded tyres on road surfaces has demanded a new method for testing aggregate abrasion resistance. Some aggregates with rather low impact values can rapidly be worn out in the road. Tests commissioned by the Swedish Road Administration, mainly in the VTI's circular road simulator, have shown that a method, similar to the British Abrasion Test (BS 812), is classifying the aggregate according to observed wear resistance $[1,2]$. The test has, however, been modified and emery flour has been used as abrasive powder instead of natural sand. The 
powder consumption has been considerably reduced and the result is calculated in a different way. This test method is now tentatively prescribed in the Swedish Road Administration directives [3]. A similar method has been developed in Norway and favourable correlation has been noticed with wear by studded tyres both in road simulator and test roads [4]. A good correlation exists between the two abrasion test methods. These are, however, unsuitable for very heterogeneous aggregates.

Test roads, where different aggregates are studied, have been constructed rather late in Sweden and have not yet been totally evaluated. Results are to be found from a test surface experiment, where different aggregates have been studied in a single suriace dressing.

\section{Description of the test surfaces}

The test surfaces have been applied on road E4, at Alberga, appr. $130 \mathrm{~km}$ south of Stockholm. They have a size of only $1 \times 2 \mathrm{~m}$ with the longer side in the outer wheel track. The average daily traffic is 9400 wehicles and the speed limit $90 \mathrm{~km} / \mathrm{h}$. In winter 1980 the frequency of vehicles with studded tyres was $50.4 \%$. The test surfaces were applied in June 1979 in connection with a double surface dressing, a regular maintenance operation. Plastic fabric was placed on the road surface which consisted of asphaltic concrete, before spreading binder and aggregate. The fabric was then rolled away and test surfaces applied in a realistic way by spreading $1.9 \mathrm{~kg} / \mathrm{m}^{2}$ cationic bituminous emulsion and aggregate from a binder tank and aggregate spreader respectively.

\section{Aggregates}

The aggregates studied and the results from laboratory tests appear in table 1 . The flakiness and impact values have been determined for size $11.2-16.0 \mathrm{~mm}$, abrasion values for size 8.0-11.2 mm. Aggregates, originating both from quarried rock and crushed gravel, have been tested. The characteristics of the aggregates have been varied, quartzite and porphyry-rich gravel, have for example low abrasion values (good wear resistance) amphibolite, diorite and two micarich gneisses have, on the contrary, high abrasion values. Diabase has a low impact value (good aggregate strength), but rather high abrasion value, due to the absence of the hard mineral quartz. There is no relationship betwe abrasion and impact values for the test materials (corre) tion coefficient $r=0.57$ ).

To be able to study the influence of the aggregate charac1 ristics. determined by the petrographic composition, all t] material necessary for a test surface was sieved to a si 11.2-16.0 mm. The flakiness values were not the same $f$ the aggregates, but the variations are not excessive (Tab. 1 Furthermore, the particle shape was varied for two aggr gates through sieving on slotted sieves so that both "cubica and flaky aggregates (flakiness indexes 1.1 and 1.5 respe tively) could be studied (see Tab. 2).

\section{Investigations of the test surfaces}

It is difficult to measure directly the wear on a surfar dressing. In France, a photogrammetric method has bee tested [5]. The macrotexture depth is easier to measu: than the direct wear and must be considered to adequate] characterize the condition of a road surface, for examp the speed dependence of the skid resistance on a wet roa is related to the macrotexture [6].

Tab. 1: Aggregates in test surfaces and results from laboratory tests

\begin{tabular}{|c|c|c|c|c|c|}
\hline Aggregate & $\begin{array}{c}\text { Sw } \\
\text { Flakiness } \\
\text { value }\end{array}$ & $\begin{array}{c}\text { Sw } \\
\text { Impact } \\
\text { value }\end{array}$ & $\begin{array}{c}\text { Sw } \\
\text { Abrasion } \\
\text { value }\end{array}$ & $\begin{array}{l}\text { Density } \\
\mathrm{kg} / \mathrm{dm}^{3}\end{array}$ & $\begin{array}{c}\text { Averagt } \\
\text { particle } \\
\text { weight" } \\
\text { g }\end{array}$ \\
\hline Quartzite & 1.35 & 48 & 55 & 2.65 & 4.81 \\
\hline $\begin{array}{l}\text { Gravel, mainly } \\
\text { porphyry }\end{array}$ & 1.34 & 34 & 62 & 2.64 & 3.92 \\
\hline $\begin{array}{l}\text { Gravel, mainly } \\
\text { granite }\end{array}$ & 1.33 & 41 & 102 & 2.68 & 3.67 \\
\hline Diabase & 1.38 & 25 & 119 & 2.97 & 3.90 \\
\hline $\begin{array}{l}\text { Gravel, mainiy } \\
\text { gneiss }\end{array}$ & 1.41 & 60 & 149 & 2.67 & 3.64 \\
\hline $\begin{array}{l}\text { Gneiss, } \\
\text { micaceous }\end{array}$ & 1.36 & 36 & 143 & 2.76 & 3.82 \\
\hline Amphibolite & 1.42 & 58 & 196 & 3.06 & 3.57 \\
\hline $\begin{array}{l}\text { Diorite, coarse } \\
\text { grained }\end{array}$ & 1.36 & 60 & 171 & 2.76 & 3.57 \\
\hline $\begin{array}{l}\text { Granite, fine } \\
\text { grained }\end{array}$ & 1.39 & 37 & 79 & 2.65 & 3.77 \\
\hline
\end{tabular}

*Corrected to an "average" density of $2.66 \mathrm{~kg} / \mathrm{dm}^{3}$.

Tab. 2: Results of measurements of texture depth with sand patch-method and laser profilometer. Results from judgement by expert panel.

\begin{tabular}{|c|c|c|c|c|c|c|c|c|}
\hline \multirow{2}{*}{ Aggregate in test surface } & \multicolumn{4}{|c|}{ Texture depth sand patch (mm) } & \multicolumn{3}{|c|}{$\begin{array}{l}\text { Texture depth, laser } \\
\text { profilometer }(\mathrm{mm})\end{array}$} & \multirow{2}{*}{$\begin{array}{c}\text { Rating } \\
\text { (expert } \\
\text { panel) }\end{array}$} \\
\hline & 7906 & 8004 & 8105 & 8109 & 7909 & 8105 & 8109 & \\
\hline 1 Quartzite & 4.12 & 2.21 & 1.84 & 1.37 & 1.33 & 1.17 & 0.81 & 5 \\
\hline 2 Gravel. rich in porphyry & 3.64 & 1.97 & 1.56 & 1.21 & 1.43 & 1.20 & 0.89 & $4-5$ \\
\hline 3 Gravel, granitic & 3.97 & 1.52 & 0.83 & 0.73 & 1.32 & 0.97 & 0.55 & 4 \\
\hline 4 Diabase & 3.57 & 1.57 & 0.92 & 0.82 & 1.41 & 1.11 & 0.74 & 4 \\
\hline 5 Gravel, rich in oneiss & 3.50 & 1.24 & 0.69 & 0.60 & 1.24 & 0.86 & 0.42 & 3 \\
\hline 6 Gneiss, micaceous & 3.47 & 1.21 & 0.55 & 0.50 & 1.42 & 0.83 & 0.38 & 3 \\
\hline 7 Amphibolite & 3.25 & 0.71 & 0.40 & 0.34 & 1.30 & 0.56 & 0.29 & 1 \\
\hline 8 Dionite. "cubic" & 3.97 & 1.24 & 0.53 & 0.46 & 1.53 & 0.89 & 0.43 & $2 \cdot 3$ \\
\hline 9 Diorite. "normal" & 3.55 & 1.02 & 0.47 & 0.41 & 1.30 & 0.69 & 0.31 & 2 \\
\hline 10 Diorite. "Naky" & 2.95 & 0.97 & 0.42 & 0.37 & 1.05 & 0.61 & 0.30 & 1 . \\
\hline 11 Granite. "flaky" & 4.36 & 1.49 & 0.67 & 0.62 & 1.36 & 1.02 & 0.57 & 3 \\
\hline 12 Granite, "normal" & 3.85 & 1.59 & 0.99 & 0.78 & 1.42 & 1.18 & 0.68 & 4 \\
\hline 13 Granite. "cubic" & 3.53 & 1.62 & 1.02 & 0.82 & 1.55 & 1.33 & 0.82 & 4 \\
\hline
\end{tabular}


:e condition of the test surfaces has been mointored by gular inspections. photographic recordings. surface casts id measuring of road surface macro-textures, the latter Jth according to the well-known sand-patch method and ie VTI's contactless laser profilometer. The latter gives ce road surface profile from which the average texture pth is automatically recorded. The laser moves on a one eter long horizontal bar. With the aid of a lens system, the tical axis of which forms a $30^{\circ}$ angle to the laser beam, $e$ light spot is reproduced on a light-sensitive sensor. The ssition of the light spot on the sensor is related to the stance of the road surface and influences electrical znals monitored from the sensor.

ae condition of the test surfaces was assessed in autumn 381 by an expert panel. After that samples of the aggreites were removed for laboratory testings by careful sating of the bituminous binder.

\section{Measurements of macrotexture depth}

he macrotexture of surface dressings is influenced by gregate factors as embedding of the particles in the undering road surface, orientation of the particles by traffic $c$, especially during the first period after laying. In the $\mathrm{K}$, where no studded tyres are used, the macrotextures of surface dressings with nominal sizes 12 and $19 \mathrm{~mm}$, ive been studied during a 12-year long period [6]. The acrotextures (sand patch measurements) decrease mostly sring the first year but to a lesser degree also during the llowing ones.

he macrotexture depth decrease depends on the hardass of the underlying pavement surface. The influence of te embedment and orientation of the aggregates should ave been reasonably constant for the different test surfangs. Loosening of single particles has not occurred to any gnificant extent.

nly sand-patch measurements were made on the newly id surfacings in May 1979. The first measurement with ser profilometer was performed in October the same ear (Tab. 2). According to the sand-patch method, the ewly laid single surface dressings had in 1979 macrotexire depths of $3-4 \mathrm{~mm}$, but the values decrease and have ven for the most wear resistant aggregates approximately een halved the next year. In spring 1981 a further. but naller decrease can be observed. Also a further decrease ccurred during the summer. according to the autumn leasurement.

he macrotexture depth measurements with the laser profimeter show that the level of the values is lower than for and patch measurements, a fact that has also been observed $y$ the TRRL [7]. Their vehicle-mounted laser profilometer las, however. of a different construction. The most-wearesistant aggregates show the greatest difference in the racrotexture depth values according to measurements rith both methods. With increasing wear. the differences ecome smaller. According to subjective observations. the ifferences in macrotexture depth between the aggregates re exaggerated by the sand patch measurements, especially or the lightly worn surfaces.

he macrotexture depths from both measurements are set n relationship in figure 1 . Because the first measurements n 1979 were made on different occasions, these values do lot fall to the same curve as the values from the later neasurements. In the diagram. the scattering of the values rom the same measurement increases with time because of he influence of the different wear of the aggregates. The aser profilometer seems to give the most relevant values ind only these are considered in the following text.

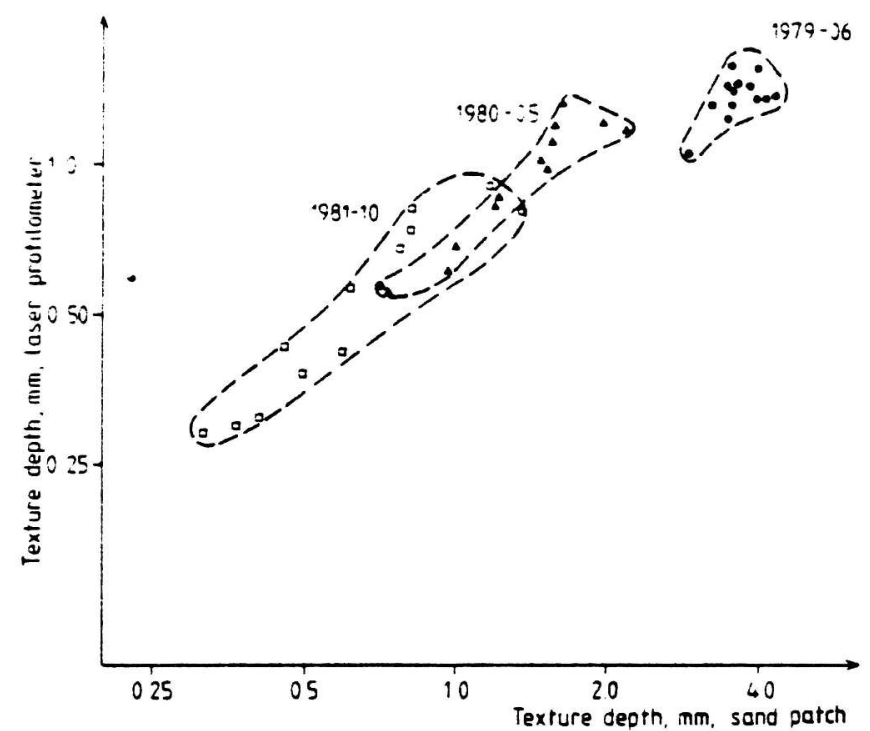

Fig. 1 : Relationship between measurements of texture depth, sand-parch and laser profilometer methods.

The changes in macrotexture depth are rather small at the beginning, when the main infiuencing factor is the particle shape. "Cubical" aggregates have the highest and the flaky ones tend to have the lowest values. The differences between the aggregates increase with wear. If only aggregates with "normal" particle shapes are examined, the highest values for macrotexture depth are obtained for aggregates with low abrasion values, the most wear-resistant are quartzite and porphyry-rich gravel, both rich in the hard quartz mineral. Diabase, with a rather high abrasion value, has also given good results and obviously the exceptionally good aggregate strength compensates for the lack of hardness. The same three aggregates. when tested in asphaltic concrete in the VTI's road simulator, have also given the best resistance to studded tyre wear [2]. The lowest texture depths have been obtained for aggregates with high abrasion values. namely amphibolite. two mica-rich gneisses and diorite. The three first mentioned aggregates have also been tested in the road simulator with poor results [2].

4.2. Relationship between texture depths, changes in macrotexture depth and results from tests on aggregates

The change of macrotexture depth has been calculated in such way that the influence of particle embedment and orientation. mainly occuring the first summer, has not been considered. The macro-texture change is therefore calculated for the period October 1979-October 1981.

The results from the aggregate tests (Tab. 1) have been set in relationship to the macrotexture depth only for aggregates with "normal" particle shapes. A good relationship (correlation coefficient $r=0.92$ ) results between the abrasion value and the macrotexture depth according to the last measurement (October 1981). figure 2. This also applies to the relationship between the change in macrotexture depth and the abrasion value $(r=0.59)$. However. no relationship is obtained between the macrotexture depth change and the impact value $(r=0.44)$. The conclusion must be that the change in the surface macrotexture mostly depends on a slow abrasive process and not so much on crushing of the aggregates.

In $\mathrm{LK}$ a test road has been performed with different aggregates in single surface dressings [8]. A good linear relation- 


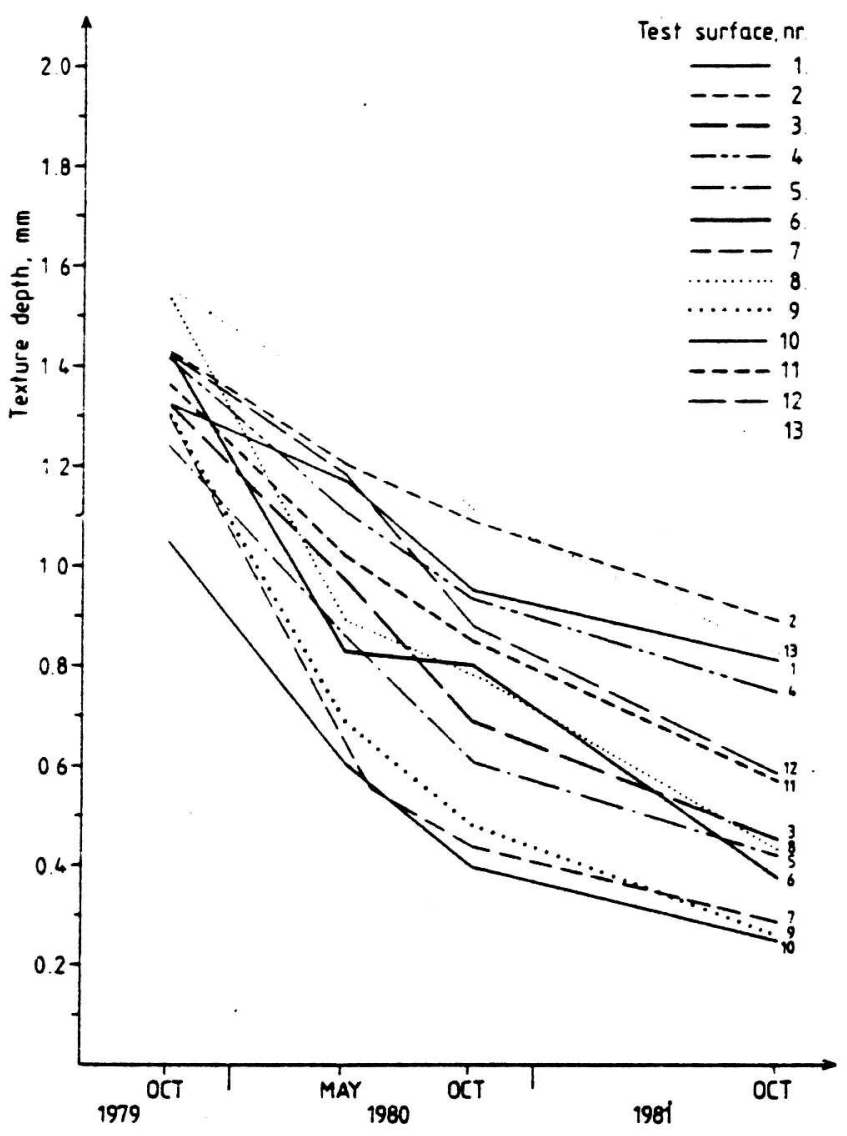

Fig. 2: Change of texture depth (obtained with laser profilometer) for test surfaces. Aggregate type and particle shape in table 1 and 2.

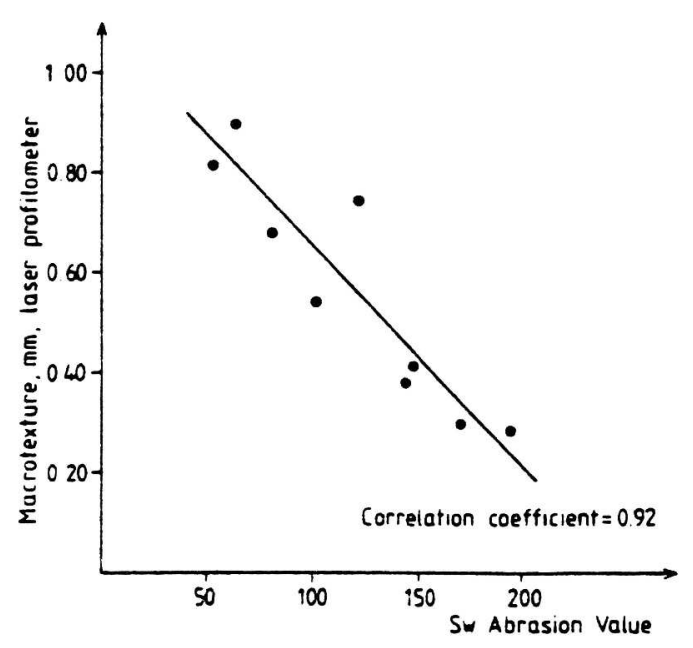

Fig. 3 : The macrotexture of test surfaces related to the $S w$. abrasion value for the aggregates.

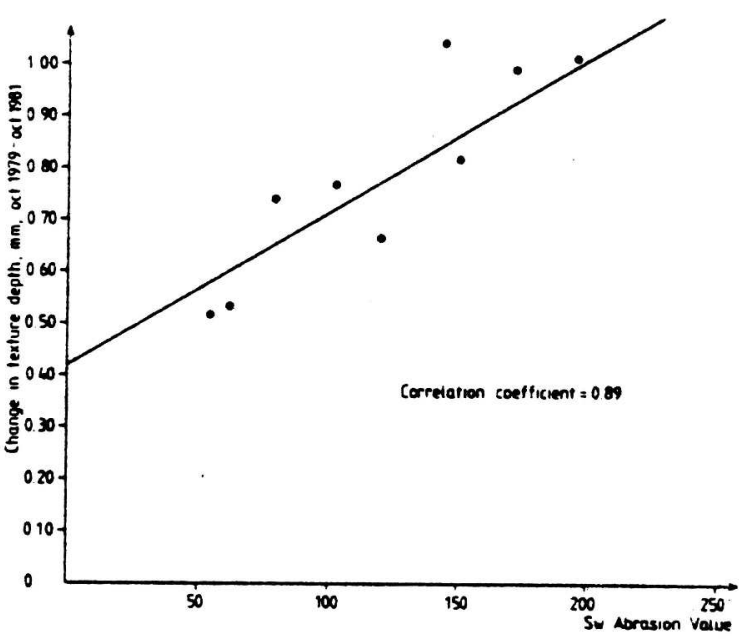

Fig. 4: Relationship between the Sw. Abrasion Value and change in macro-texture depth, measured with laser profilometer in October 1979 and October 1981.

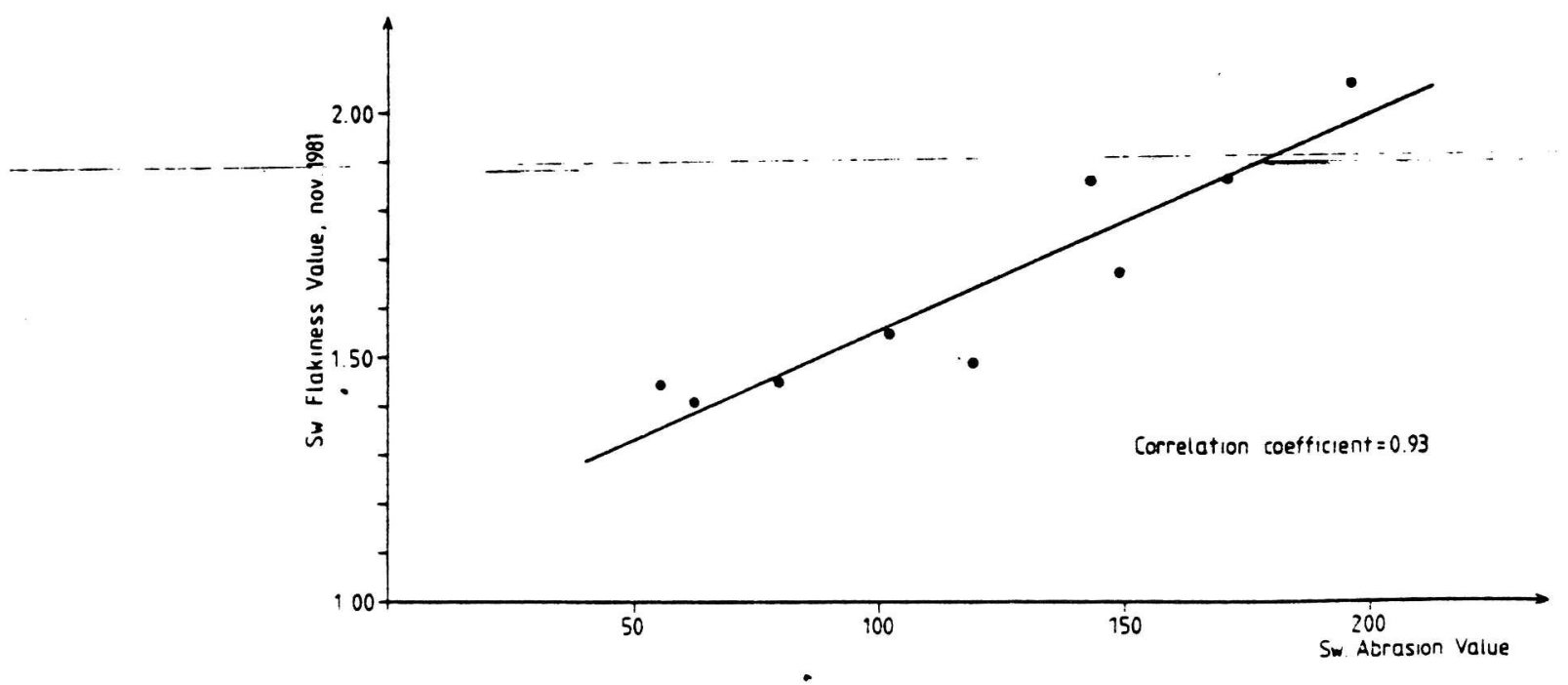

Fig. 5: Relationship between $\mathrm{Sw}$. abrasion value and $\mathrm{Sw}$ flakiness value for aggregates worn in test surfaces. 
up was obtained between the British aggregate abrasion st and the macrotexture depth after 9 years. No such lationship exists with the British aggregate chrushing test.

French test road experiment [9] with surface dressings, so established a correlation between surface wear (photoammetric measurements) and the abrasion resistance of e aggregate determined bu the Microdeval test (an wet rasion test) but not the Los Angeles test (mainly an Ipact test). It has been shown aiso in Hungary [10] that ere is a linear relation between the change of macroxture depth of hot-rolled asphalt surfacings and the itish abrasion value. It can be said that the abrasion resisnce of aggregates is a matter of importance not only in untries where studded tyres are used.

Irmer studies made in Norway [4] and Sweden [2] have own that the product value between aggregate abrasion d impact strength values has given the best correlation th the studded tyre wear of asphaltic concrete. That iult cannot be confirmed for the test surfaces, the abrain value has given a slightly better result than the product ue $(r=0.89$ and 0.84 respectively).

certain crushing of the aggregates has occurred in the t surfacings according to examination of photographs $d$ the aggregate samples taken from the road (chapter 3.). Some crushing occurs already at compaction, but st of it is caused by traffic stresses.

\section{i. Investigation of aggregate samples removed from the id}

has been observed that the wear of studded tyre wear ises the aggregates in the road surface to become more I more flaky. The flakiness values of aggregates in the t surfaces have also increased (Tab. 3). For aggregates h "normal" initial particle shapes, there is a good correon between the abrasion values and the flakiness values

Tab. 3 : Tests on aggregate sampled from the test surfaces in October 1981.

\begin{tabular}{|c|c|c|c|c|}
\hline Aggregate & $\begin{array}{c}\text { Sw. } \\
\text { Flakiness } \\
\text { index }\end{array}$ & $\begin{array}{c}\% \text { passing } \\
11.3 \mathrm{~mm} \\
\text { sieve }\end{array}$ & $\begin{array}{c}\text { Sw. } \\
\text { Impact } \\
\text { value }\end{array}$ & $\begin{array}{c}\text { Average } \\
\text { particle } \\
\text { weight, }\end{array}$ \\
\hline Quartzite & 1.44 & 38.0 & 55 & 3.78 \\
\hline $\begin{array}{l}\text { ! Gravel, mainly } \\
\text { porphyry }\end{array}$ & 1.41 & 35.6 & 42 & 3.46 \\
\hline $\begin{array}{l}\text { Gravel, mainly } \\
\text { granite }\end{array}$ & 1.55 & 54.1 & 66 & 3.05 \\
\hline Diabase & 1.49 & 34.4 & 43 & 3.34 \\
\hline $\begin{array}{l}\text { Gravel, mainly } \\
\text { gneiss }\end{array}$ & 1.68 & 67.5 & 78 & 3.00 \\
\hline $\begin{array}{l}\text { Gneiss } \\
\text { micaceous }\end{array}$ & 1.87 & 57.9 & 61 & 3.15 \\
\hline Amphibolite & 2.12 & 79.6 & 79 & 2.93 \\
\hline $\begin{array}{l}\text { Diorite } \\
\text { "cubic" }\end{array}$ & 1.65 & 52.1 & 66 & 3.65 \\
\hline $\begin{array}{l}\text { Dionte } \\
\text { "normal" }\end{array}$ & 1.87 & 70.1 & 85 & 2.87 \\
\hline $\begin{array}{l}\text { Dionte } \\
\text { "flaky" }\end{array}$ & 1.98 & 81.2 & 81 & 3.01 \\
\hline $\begin{array}{l}\text { Granite } \\
\text { "flaky" }\end{array}$ & 1.55 & 36.5 & 52 & 3.15 \\
\hline $\begin{array}{l}\text { Granite } \\
\text { "normal" }\end{array}$ & 1.45 & 28.0 & 45 & 3.39 \\
\hline $\begin{array}{l}\text { Granite } \\
\text { "cubic" }\end{array}$ & 1.35 & 19.4 & 44 & 3.69 \\
\hline
\end{tabular}

resulting after road wear $(r=0.93)$, figure 5 . Also the impact test has been determined on the worn aggregates from the road. The values have increased to a varying extent in comparison with the original ones because of the worn, flakier and therefore weaker particles (see Tab. 1 and 3).

The aggregate samples have also been sieved to determine the degree of crushing that has occurred in the road. If material passing $11.2 \mathrm{~mm}$ sieve is considered and related to the impact values, a certain relationship is found $(\mathrm{r}=$ 0.81 ), figure 6 . If material $<8.0 \mathrm{~mm}$ is considered, the relationship is better, $r=0.84$. The conclusion must be that the crushed aggregates are still effective in the surface dressings due to good adhesion with the binder. This fact can also clearly be seen in photographs taken at different times. Such behaviour of aggregates in the road has been named "post-failure" condition [11]. It can also be observed that the binder has been pressed up in cracks formed in the aggregates. Such action is more difficult e.g. in an asphaltic concrete when the binder even in warm weather is stiffened by filler and fine aggregate. Normally no adhesion promoting agent is used in asphaltic concrete. It has also been observed in another test road on the E4 near Gävle that the same quartzite does not perform as well as expected in an asphaltic concrete, obviously because particle fragments formed by crushing are lost from the road surface.

Also the average particle weight has been determined for original and worn aggregates from the road surface. It can be seen (Tab. 3) that the "cubical" aggregates have lost more weight than "normal" or flaky ones. Probably the former have such protruding edges in the road surface that are easily worn away.

If the loss of average particle weight in the road (corrected for differences in density) is correlated with the abrasion value, it is seen that other aggregates than quartzite show some relationship (Fig. 7). Probably this very hard, but rather brittle aggregate has lost weight in a different way to the others, e.g. more splitting of sharp edges has occurred.

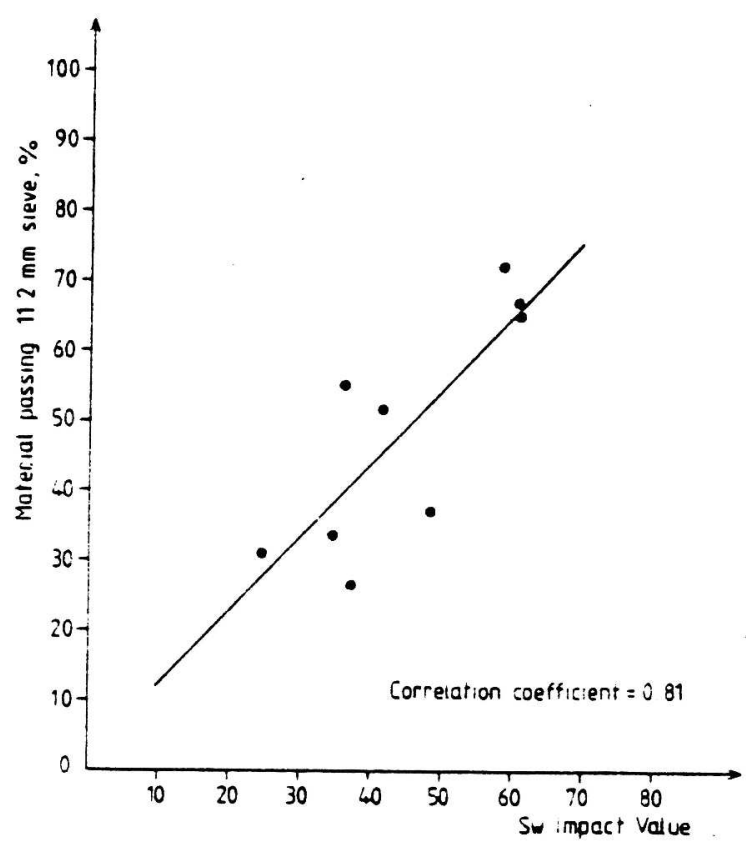

Fig. 6: The relationship between crushing of the aggregates in test surfaces and $\mathrm{Sw}$. impact value. 


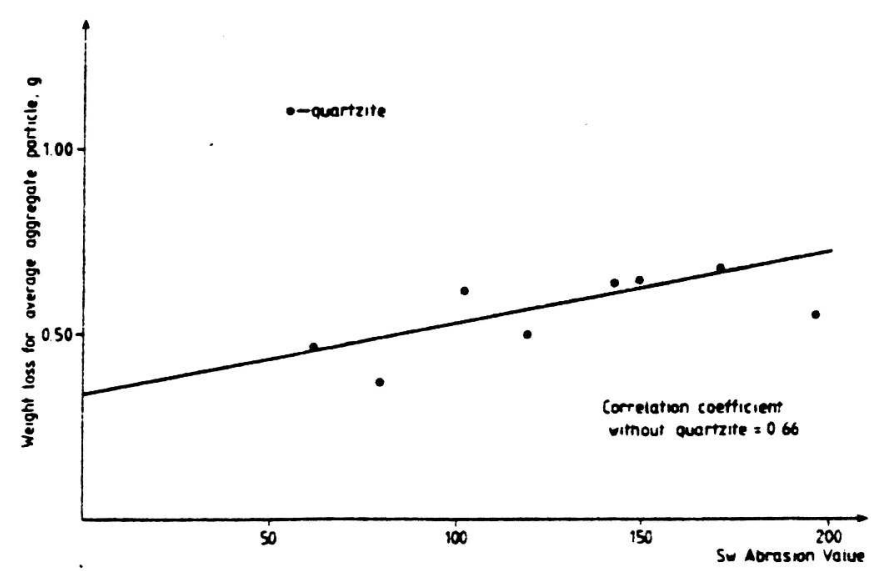

Fig. 7 : Relationship between Sw. Aggregate Abrasion Value and weight loss (corrected to density $2.66 \mathrm{~kg} / \mathrm{dm}^{3}$ ) for average aggregate particle with "normal" flakiness in test surface.

\subsection{Inspection by an expert panel}

The condition of the test surfacings was judged in October 1981. A scale ranging from 1 to 5 was used (Tab. 3). Quartzite and porphyry-rich gravel, that is aggregates with low abrasion values, achieved the highest nominations. The lowest ones were observed in aggregates with high abrasion values. Good agreement is obtained with the results from surface macrotexture depth measurements.

\section{Discussion and conclusions}

It can be observed that all aggregates with abrasion values exceeding 150 have been ranked lower than 3 by the expert panel and their functional capacity can be considered near the point after two years in the road with the specific traffic.

The macrotexture depth is $>0.70 \mathrm{~mm}$ for the most wearresistant aggregates, judged good by the expert panel, and $<0.50 \mathrm{~mm}$ for the insufficient ones. According to Swiss [12] experience the surface texture (sand-patch measurements) should be $0.6-1.00 \mathrm{~mm}$ for roads carrying fast traffic. In the UK the sand-patch texture depth for experimental surface dressings have been $0.8-1.8 \mathrm{~mm}$ after 12 years traffic [6].

The measurement of the surface macrotexture depth and its change with time has made it possible to characterize the condition of the single surface dressings and consequently the aggregate quality. The laser profilometer has given lower values than the sand-patch measurement, the difference being greatest for the less worn surfacings. The first method is considered the more reliable one.
The functional life of the aggregates is mainly determ by their wear resistance as determined by an abrasion The particles are wom more and more flaky in the surface. The strength properties are of secondary import in the case of proper aggregate-binder adhesion as in a pieces crushed particles continue to function in the surface. The particle shape is also of importance and cul particles give the highest initial macrotexture depth. 1 aggregate has poor abrasion resistance it can be impr to a certain degree by obtaining as "cubical" particle sl as possible by adequate processing operations.

\section{References}

[1] HÖBEDA P. : Wear of studded tyres on aggregate. An ir tigation in road simulator (in Swedish). VTI Internrap $25,1971$.

[2]ROSENGREN Å., HÖBEDA P. : The influence of eggre, quality on the wear resistance of dense asphaltic concr An investigation in road simulator (in Swedish). VTI Rap! $125,1977$.

[3] BYA 84. : Swedish Road Administration. Construction spe Cations, 1984, (in Swedish).

[4] RYAN S. : The wear of asphaltic surfaces (in Norwegi: Norges Tekniske Högskole. Institutt for Veg- og Jernb: byggning. Trondheim 1978.

[5] TOURENQ C., LEFRANC J. : Determination de l'usure d revêtement routier par photogrammêtrie. Bulletin de Liai des Leboratoires des Ponts et Chaussées 58, mars-avril 19

[6] JACOBS F.A. : $M 40$ High Wycombe by-pass : results o bituminous surface-texture experiment. Transpert Road Research Laboratory, Laboratory Report 1065, 19

[7] COOPER D.R.C. : Measurement of road surface rexnun b. contactless sensor. Transport and Road Research Laborato Report 639, 1974.

[8] WISON D.S. : An experiment comparing the performunce rocdstones in surface dressing. Road Research Laboratc Report No. 46, 1966.

[9] TOURENQ C. : Quelques constatations sur l'évaluation , granulats utilisés pour le réalisation des minipleches de route nationale 20. Laboratoire Central des Ponts et Chaussé février 1972 (unpublished report).

[10] REZNAK L. : Anforderung an Gesteinskörnungen im Hinbli auf die Moderne Strassenverkehrstechnik in Ungarn. $F$ schungsgesellshaft für das Strassenwesen im Österreischich Ingenieur- und Architekten-Verein Heft nr 65, 1974.

[11] EPPENSTEINER W. : Die Beobachtung des Splittkornverh tens in bituminös gebundenen Strassendecken. Forschun gesellschaft für das Strassenwesen im Österreischich. Ingenieur- und Architekten-Verein, Heft 70.

[12] ZIPKES E. : Influence de la structure de revettement $s$ l'écoulement des eaux et les taux d'accidents. OECD. Reche che Routière. Le drainage des Routes. Paris 1978. 
Forskar för ett liv i rörelse.

Statens väg- och transportforskningsinstitut har kompetens och laboratorier för kvalificerade forskningsuppdrag inom transporter och samhällsekonomi, trafiksäkerhet, fordon, miljö samt för byggande, drift och underhåll av vägar och järnvägar. 